\title{
MORAINE IN-TRANSIT AS PARENT MATERIAL FOR SOIL DEVELOPMENT AND THE GROWTH OF VALDIVIAN RAIN FOREST ON MOVING ICE: CASA PANGUE GLACIER, MOUNT TRONADOR
}

\author{
(LAT. $41^{\circ} 10^{\prime}$ S), CHILE
}

\author{
by \\ Jorge Rabassa, \\ (Department of Geography, Universidad Nacional del Comahue, Av. Argentina 1400, \\ 8300 Neuquén, Argentina) \\ Sigfrido Rubulis, \\ (Hidronor S. A., C.C. 1207, 8400 San Carlos de Bariloche, Argentina) \\ and Jorge Suarez \\ (Argentine Institute of Nivology and Glaciology, C.C. 330,5500 Mendoza, Argentina)
}

\section{ABSTRACT}

Casa Pangue glacier is a regenerated valley glacier, covered by supraglacial moraine of variable thickness ( 1 to $3 \mathrm{~m}$ ). Seven moraine in-transit arcs have originated from avalanches falling on the ice from the steep walls at the head of the valley. The debris has been relocated by glacier movement, and vegetation has become established on areas with sediment cover. Primitive soil has developed very rapidly, probably in less than 100 a. Chemical analysis of soil samples show that it is acid ( $\mathrm{pH} 4.6$ to 4.7 ), nitrogen and organic matter are absent, calcium content is low, and potassium content is high. Pedogenic processes are mostly related to intense chemical weathering, under conditions of more than $4000 \mathrm{~mm} \mathrm{a}^{-1}$ of total precipitation.

The plant communities established on the moraine are essentially similar to the Valdivian rain forest that characterizes the region. The most frequent tree is "coihue" (ivothofagus dombeyi), followed by "teniú" (Weinmannia trichosperma) and "notro" (Embothrium coceineum). One specimen of $N$.dombey $i$ was found to be $18 \mathrm{~m}$ ta 11 and $0.62 \mathrm{~m}$ in diameter; many others were taller than $12 \mathrm{~m}$ and reproduction was abundant. Dendrochronological analysis indicates a minimum age of 45 a for the aldest tree. Other plants found here are shrubs, some hemiparasitic and creeping plants, mosses, 1 ichens, ferns, and fungi.

Using air photographs of 1942, 1953, 1970, and our own oblique photographs of 1978, taken from the summit of a neighbouring peak $7200 \mathrm{~m}$ above the glacier tongue, average surface velocity of the glacier tongue was estimated at 22.5 $m a^{-1}$ for the lower and intermediate sectors where the trees are growing. If the total length of the regenerated valley glacier is taken into account, the mean annual movement rate is $35.0 \mathrm{~m} \mathrm{a}^{-1}$. If this value is extra- polated over the last $45 \mathrm{a}$, the trees have moved an average distance of at least $1000 \mathrm{~m}$ in that time.

The discovery of established communities (also observed at Río Blanco glacier, southwest of Mt Tronador) on moving ice constitutes an event not previously recorded in glaciological literature. Some significant aspects are discussed: time lapse for soil development on moraine deposits, primary plant succession on moraine deposits, the need of stable ground for plant colonization, the absolute validity of radiocarbon dating of glacier advances using fossil wood found within terminal moraines, and the validity of lichenometric techniques in deglaciated terrain.

\section{INTRODUCTION}

In only a few places in the world, trees have been observed growing on supraglacial till and, in most of them, the ice has been considered as dead or stagnant (Russell 1893, Tarr and Martin 1974, Ode11 1948, Miller 1957, Sharp

1958, Clayton 1964, Post 1967, Porter and Carson 1971, Post and Streveler 1976). In these examples, glacier ice has lost its mobility and it provides a rather stable substratum for pedogenic development and vegetation growth. This stability is disrupted only by melting of the ice below the rill. However, there is a reference to the Agassiz Glacier, Alaska (Seton Karr 1887: 85) as being an advancing glacier with a thick forest growing along the extremity of its ice-cored, moving, terminal moraine. (We thank Dr Austin Post for this reference. Dr Post also mentions that this moraine is now a stagnant portion of the Malaspina Glacier (written communication).) Reid 1969[b], 1970[a], 1970 [b] describes trees growing on the supraglacial drift of Martin River Glacier, Alaska, on a partially active intermediate zone.

Dr Stephen C. Porter also informed us that he 
and $\mathrm{Dr}$ Giuseppe Orombe $11 \mathrm{i}$ found $1.5 \mathrm{~m}$ ta 11 larch trees growing on an active glacier in the Italian Alps (written communication). Matthews (1973) reports the finding of lichens growing on medial moraines or active supraglacial debris. Heusser (1972) describes mosses growing on a thin film of dust or stones covering the bare ice of Gilkey Glacier, Alaska.

During field work for the glacier inventory of the northern Patagonian Andes (Rabassa and others 1980 ) we had the opportunity of climbing the international boundary range, immediately north of Mt Tronador, and of observing the total extent of Casa Pangue glacier. The surface of this debris-covered glacier was found to be covered by tree communities, which,al though scattered all over it, were concentrated on several moraine intransit arcs. In April 1979 the glacier was visited and the three outermost morainic arcs studied. These arcs are composed of supraglacial till and they display the growth of well-adapted, extremely heal thy tree communities. Trees and other plants also extend over the surface of the glacier between arcs, although the density of vegetation is much lower. Air photographs show that tree communities also grow on Rio Blanco glacier (south-west slope of Mt Tronador) but in this case they extend more uniformly over the surface. Access to Rio Blanco glacier is difficult and it has not been possible for us to visit it yet. Nevertheless, the general environmental conditions and glacial processes look very much the same and show that the case of Casa Pangue glacier is not unique.

This paper presents the finding of welldeveloped trees growing on active ice and the processes leading to the genes is of supraglacial till on the glacier. Some questions concerning radiometric dating and lichenometric techniques are discussed.

\section{GEOGRAPHY}

Casa Pangue glacier is located on the northern slope of Mt Tronador (1at. $41^{\circ} 08^{\prime} \mathrm{S}$, long. $710^{\circ} 55^{\prime} \mathrm{W}$ ), Chile (Fig. i). Its accumulation area starts at the base of the summit (3 $556 \mathrm{~m} \mathrm{a.s.1.)} \mathrm{and} \mathrm{its} \mathrm{tongue} \mathrm{reached} 540 \mathrm{~m}$ a.s.l. on April 1979.

The lake district of south-central chile, between lat. $40^{\circ} \mathrm{S}$ and $41^{\circ} \mathrm{S}$, has an oceanic climate with abundant rainfail $\left(>4000 \mathrm{~mm} \mathrm{a}^{-1}\right.$ ). According to Heusser (1974) the climate is controlled by cyclonic storms entering the continent in rapid succession during the winter months (May to October). Polar Pacific air becomes unstable when it faces the Andean ranges. Rain and snow fall heavily on the western slopes; mean temperatures for summer and winter are 15.0 and $6.4{ }^{\circ} \mathrm{C}$, respectively. The vegetation of the region belongs to the Valdivian rain forest and the north Patagonian rain forest (Heusser 1974). The Valdivian rain forest extends from sealevel up to 650 or $700 \mathrm{~m}$ a.s.1. The north Patagonian rain forest covers the landscape above this level up to $1000 \mathrm{~m}$ a.s.1., where it is replaced by the sub-Antarctic deciduous forest and the alpine tundra. The valley of Casa Pangue glacier has very strong local relief, between $2000 \mathrm{~m} \mathrm{a.s.1}$. at the divide and $450 \mathrm{~m}$ at the valley floor. Thus, all the units described are represented within the valley.

\section{CASA PANGUE GLACIER}

\subsection{Previous work and methodology}

Casa Pangue glacier has been mentioned by Kö11 iker and others (1917), Reichert (1927), Lliboutry (1956), and Mercer (1967), among

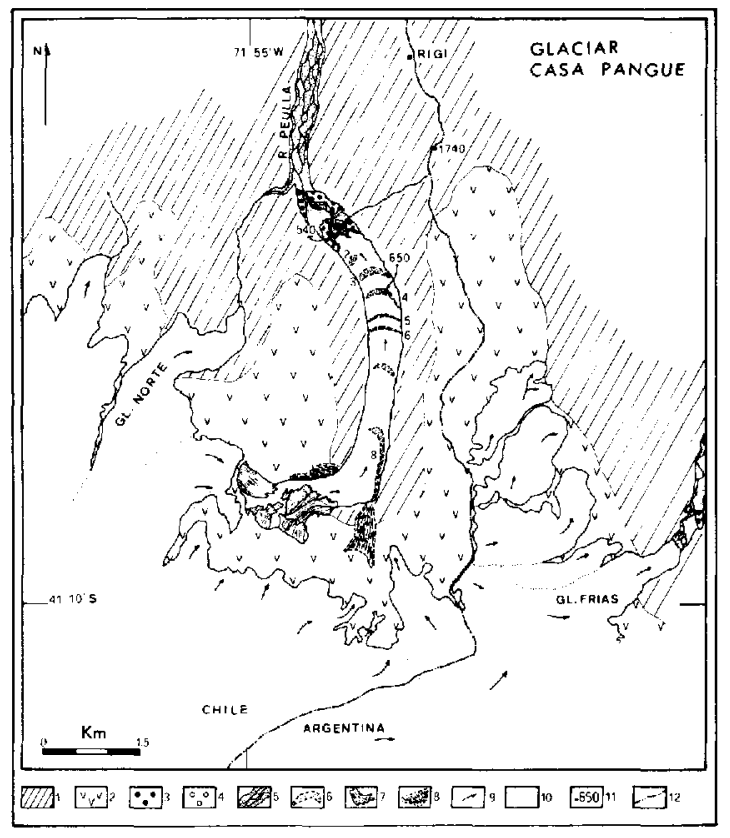

Fig. 1. Casa Pangue glacier. Map compiled from 1970 air photographs. References:

(1) Granodiorites. (2) Tronador Formation: volcanics and pyroclastic rocks. (3) Neoglacial moraines. (4) Ice-cored moraines. (5) Glaciofluvial plains. (6) Moraine intransit arcs. (7) I ce and snow avalanches. (8) Landslides and debris avalanches. (9) Ice movement. (10) Local ice shed. (11) Point of known elevation in m a.s.l. (12) International border.

others. According to Kölliker, it is a reconstituted glacier covered with debris on which shrubs were growing in 1911, when its tongue reached $370 \mathrm{~m}$ a.s. 1 .

The geology of the area is composed of Cretaceous granodiorites, overlain by PlioPleistocene basalts, breccias and tuffs of the Tronador Formation. These volcanic units correspond to the eruptions of Mt Tronador, a basaltic shield volcano superimposed on a late Tertiary palaeorelief. In the valley, we observed glacigenic deposits corresponding to the Llanquihue glaciation (Heusser 1974, Mercer 1976, Heusser and Flint 1977). This is also called the El Salto glaciation by Paskoff (1977) and is Wisconsin in age. In Argentina its equivalent is the Nahuel Huapi glaciation (Flint and Fidalgo 1964). Deposits of the last neoglacial readvance are found near the glacier snout. The movement of the glacier ice and, therefore, of the morainic arcs, and the recession of the ice front have been assessed by the methodology applied by Miller (1957) on Yakataga Glacier, Alaska. Air photographs of 1942 (approximate scale 1:40 000), 1953 $(1: 37000)$, and $1970(1: 31000)$ were used. The approximate position of the arcs and the ice front were also recorded on colour slides taken in 1978 from a peak $1100 \mathrm{~m}$ above the glacier. A map (Fig. 1) was prepared based on an enlargement of the 1970 air photographs. Elevations were estimated by means of a hand altimeter. 3.2 Vegetation

The vegetation cover extends almost continuously over the glacier surface, especially near its terminus. Conspicuous trees 
were observed growing on all morainic arcs, except arc no.8, the innermost and youngest (Fig. 1). The dominant tree is "coihue" (Nothofagus dombeyi), the evergreen southern beech. Several of the trees observed on arc no.4 (Fig. 2) were taller than $15 \mathrm{~m}$, and one of them was $18 \mathrm{~m}$ in height and $0.62 \mathrm{~m}$ in diameter. On arcs nos. 2 and $3, N$. dombeyi develop as dwarf trees, < $3 \mathrm{~m}$ in height, though the trunk diameters are of normal size. On the rest of the arcs, $N$. dombeyi have normal, erect trunks with sub-conical crowns, possibly due to the availability of open space. Other trees observed, though scarce, are "notro" (Embothrium coccineum), "teniú" (Weinmannia trichosperma), and "ulmo" (Eucryphia cordifozia). Regrowth is abundant everywhere. Shrubs, hemiparasitic and creeping plants, mosses, ferns, herbs, grasses, 1 ichens, and fungi extend all over the forested area and the wider depressions between arcs.

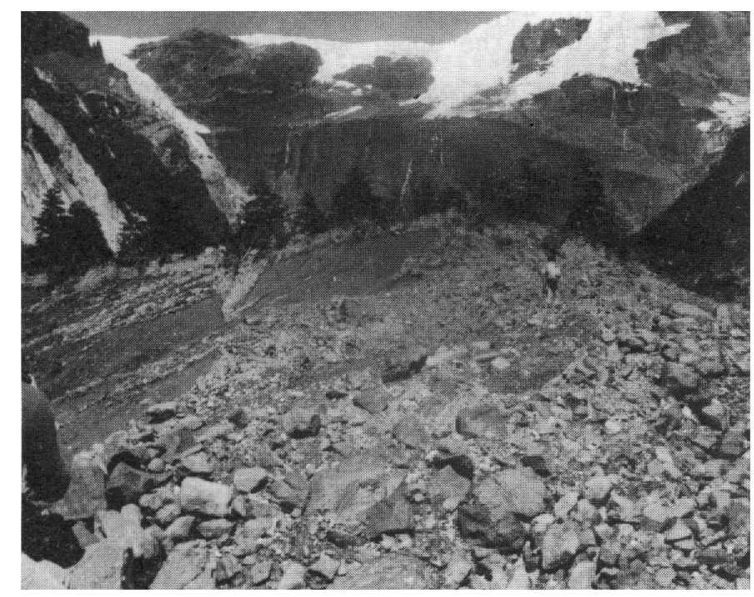

Fig. 2. Casa Pangue glacier. Moraine in-transit arc no.4. Trees (Nothofagus dombeyi) growing on supraglacial till. Thickness of the till: 2 to $3 \mathrm{~m}$. Elevation: 635 to $650 \mathrm{~m}$ a.s. 1 . Note the underlying ice, uncovered at the left side of the arc.

An outstanding feature of the community studied is that the supraglacial till on which the trees are growing is deeply cracked, due to glacier-ice movement and crevassing. Some of the cracks have affected the overlying trees, breaking the trunks up to heights of 2.5 to $3.0 \mathrm{~m}$ above their roots and pulling apart the two halves, up to $0.6 \mathrm{~m}$. However, in spite of the unfavourable conditions, most of the trees display nomal growth characteristics. Several trees were sampled for dendrochronological analysis with a Pressler core sampler. The minimum age of the oldest trees is 43 to $45 \mathrm{a}$. False rings were also observed in these samples, but not included in the counting.

3.3 Characteristics and movement of Casa Pangue glacier

Casa Pangue glacier is a regenerated valley glacier, nourished by ice and snow avalanches coming chiefly from four hanging glaciers (Fig. 3), which descend from their accumulation areas starting at $3300 \mathrm{~m} \mathrm{a.s.1.} \mathrm{At}$ $1700 \mathrm{~m}$ a.s.1., approximately, these glaciers break over a gigantic, almost vertical cliff, with a drop in elevation of more than $800 \mathrm{~m}$. In the regenerated area, snow and ice avalanches were observed, together with large landslides coming from the vertical cliffs. The iceavalanche section is almost $1.6 \mathrm{~km} \mathrm{long,} \mathrm{with} \mathrm{a}$

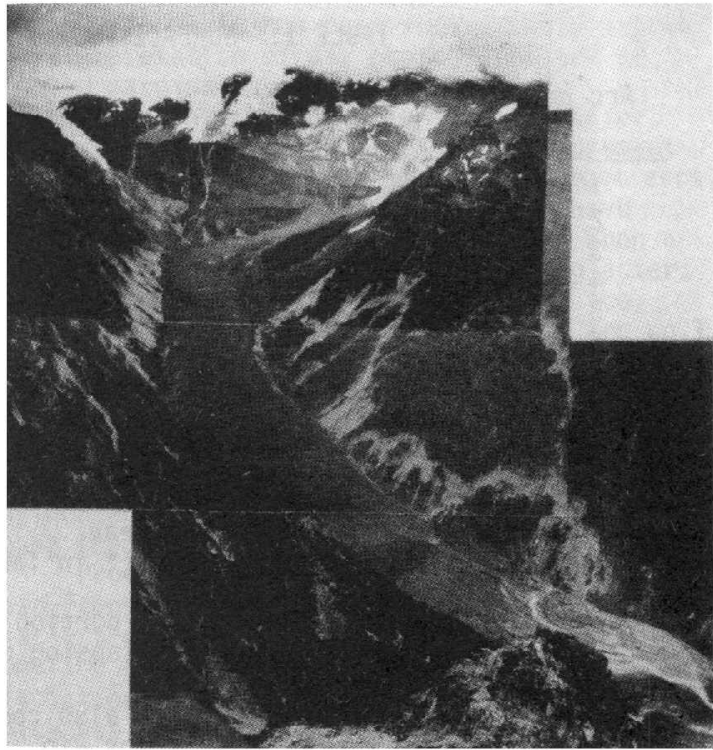

Fig. 3. Casa Pangue glacier, regenerated valley glacier. Note the upper, clean glaciers, the avalanche section, the landslide scar at the vertical cliff, the sequence of moraine in-transit arcs. The innermost, youngest arc still shows an extended tail up to the site where the landslide from the cliff reached the glacier surface. Seen from the summit of Cerro Vichadero (1 $740 \mathrm{~m} \mathrm{a.s.1.)}$.

maximum width of $1.1 \mathrm{~km}$. It is an amphitheatrelike depression with vertical walls. Moving down-slope, the ice enters a much narrower valley, $1.2 \mathrm{~km}$ long and $<0.6 \mathrm{~km}$ wide. Ice is compressed and crevassing is intense. Finally, the glacier reaches the east wall of the valley and turns abruptly northwards. At the beginning of this section, evidence of landsliding on the glacier surface was observed.

Some features of glacier-karst were observed in the lower sections, such as large depressions and sink-holes 40 to $50 \mathrm{~m}$ in diameter, and ice pillars up to $20 \mathrm{~m}$ in height. However, the glacier-karst features are more rudimentary than those observed on Rio Blanco glacier or Río Manso glacier (Rabassa and others 1978), both of these also being regenerated valley glaciers. The morainic arcs are ice crests up to $30 \mathrm{~m}$ above the level of the neighbouring depressions, with a thick cover of supraglacial debris. The lower tongue ( $3.6 \mathrm{~km}$ long) displays a sequence of seven of these arcs, which occupies a transverse position on the glacier surface, extending through most of its width. The 1942 air photographs show an outermost arc which had already disappeared by 1953, when it reached the glacier margin and collapsed. The arcs are not exactly similar. Some are wider and lower, with symmetrical transverse profiles. Some, on the contrary, are narrower and higher, with the steeper slopes facing up-glacier. The distribution of the arcs has helped in the determination of movement velocity of the glacier tongue; values are presented in Table I.

An analysis of Table I suggests that:

(1) Casa Pangue glacier is active, because some portions have moved almost $1 \mathrm{~km}$ during 1941-78.

(2) The rate of movement decreases when the arcs reach the terminal area. 
TABLE I. SURFACE MOVEMENT VELOCITY, CASA PANGUE GLACIER (LOWER TONGUE)

\begin{tabular}{|c|c|c|c|c|c|c|c|c|}
\hline \multirow[t]{2}{*}{ Arc no. } & \multicolumn{2}{|c|}{$1942-53$} & \multicolumn{2}{|c|}{$1953-70$} & \multicolumn{2}{|c|}{$1970-78$} & \multicolumn{2}{|c|}{ Totals } \\
\hline & $\mathrm{m}$ & $\mathrm{ma}^{-1}$ & $\mathrm{~m}$ & $\mathrm{ma}^{-1}$ & $\mathrm{~m}$ & $\mathrm{ma}^{-1}$ & m & $\mathrm{ma}^{-1}$ \\
\hline 1 & $>90$ & $>90.0$ & - & - & - & - & $?$ & $?$ \\
\hline 2 & 161 & 14.6 & 118 & 6.9 & 108 & $13.5\left(^{*}\right)$ & 387 & 10.8 \\
\hline 3 & 193 & 17.5 & 256 & 15.0 & 46 & 5.7 & 527 & 14.7 \\
\hline 4 & 481 & 43.7 & 309 & 18.2 & 62 & 7.7 & 852 & 23.6 \\
\hline 5 & - & - & 488 & 28.7 & 124 & T5.5 & 612 & 24.4 \\
\hline 6 & - & - & 633 & 37.2 & 187 & 23.3 & 820 & 32.8 \\
\hline 7 & - & - & - & - & 356 & 44.5 & 356 & 44.5 \\
\hline 8 & - & - & - & - & 760 & 95.0 & 760 & 95.0 \\
\hline
\end{tabular}

(3) Mean velocities are consistent, with the unique exception of the partial mean velocity for arc no.2 in 1970-78 (* in Table I).

The abnormal acceleration of this portion of the ice could be explained by collapsing of the glacier margin

(4) The estimated mean velocities are also comparable with the data available for Río Manso glacier. Colqui (1970) presents ice movement measurements in two portions of the lower tongue of this glacier: $52 \mathrm{~cm} \mathrm{~d}^{-}$ (187 $\mathrm{m} \mathrm{a}^{-1}$ ) and $16 \mathrm{~cm} \mathrm{~d}^{-1}\left(56 \mathrm{~m} \mathrm{a}^{-1}\right)$.

In a similar way, ice-front recession has been estimated (Table II).

TABLE II. ICE-FRONT RECESSION OF CASA PANGUE GLACIER

\begin{tabular}{ccc} 
Period & $\begin{array}{c}\text { Recession } \\
(\mathrm{m})\end{array}$ & $\begin{array}{c}\text { Average } \\
(\mathrm{m} \mathrm{a}-1)\end{array}$ \\
\hline $1942-53$ & -18.0 & -1.6 \\
$1953-70$ & -222.0 & -13.0 \\
$1970-78$ & -70.0 & -8.7 \\
$1942-78$ & -310.0 & -8.6
\end{tabular}

These values are very similar to those observed on the glaciers on the Argentine side of Mt Tronador (Rabassa and others 1978). 3.4 Processes of supraglacial deposition and soil development

The surface of Casa Pangue glacier is covered by supraglacial till. This sediment is composed of angular cobbles and boulders in a sandy matrix. The lithology of the gravel fractions is almost exclusively tuffs and volcanics of the Tronador Formation. Gigantic blocks are scattered on the entire surface, some of them up to $15 \mathrm{~m}$ in diameter. No apparent ordering of the blocks was observed. Till matrix is essentially sandy, with some finer fractions. The till is yellowish grey and poorly consolidated. The surface of the till is thoroughly fissured and crevassed due to the movement of the underlying ice. Some of the cracks are deep enough to uncover the ice. The occurrence of supraglacial till on Casa Pangue glacier is schematically depicted in Figure 4. Rock fragments reach the glacier surface by rock falls, and, to a lesser extent, from within the upper glaciers. Landsliding may originate from glacial undercutting of the rock wall, especially at the turn of the valley, or be provoked by earthquakes, this being a seismically active region. Debris and rock avalanches of much smaller size are also generated by the continuous action of ice avalanches from the upper glaciers (Fig. 4a). Some of the material is distributed by sliding over the ice surface, assisted by ice movement, mass-movement processes, and supraglacial streams in the nonkarst zone. Landslides at the valley bend supply Targer amounts of debris, which is redistributed by glacier movement, as can be seen in Figures 1 and 3 . Depending on the size of the landslide, the arc will extend across the glacier or it will cover only a portion of its width (Fig. 4b). Debris supply is presently restricted to the upper section of the
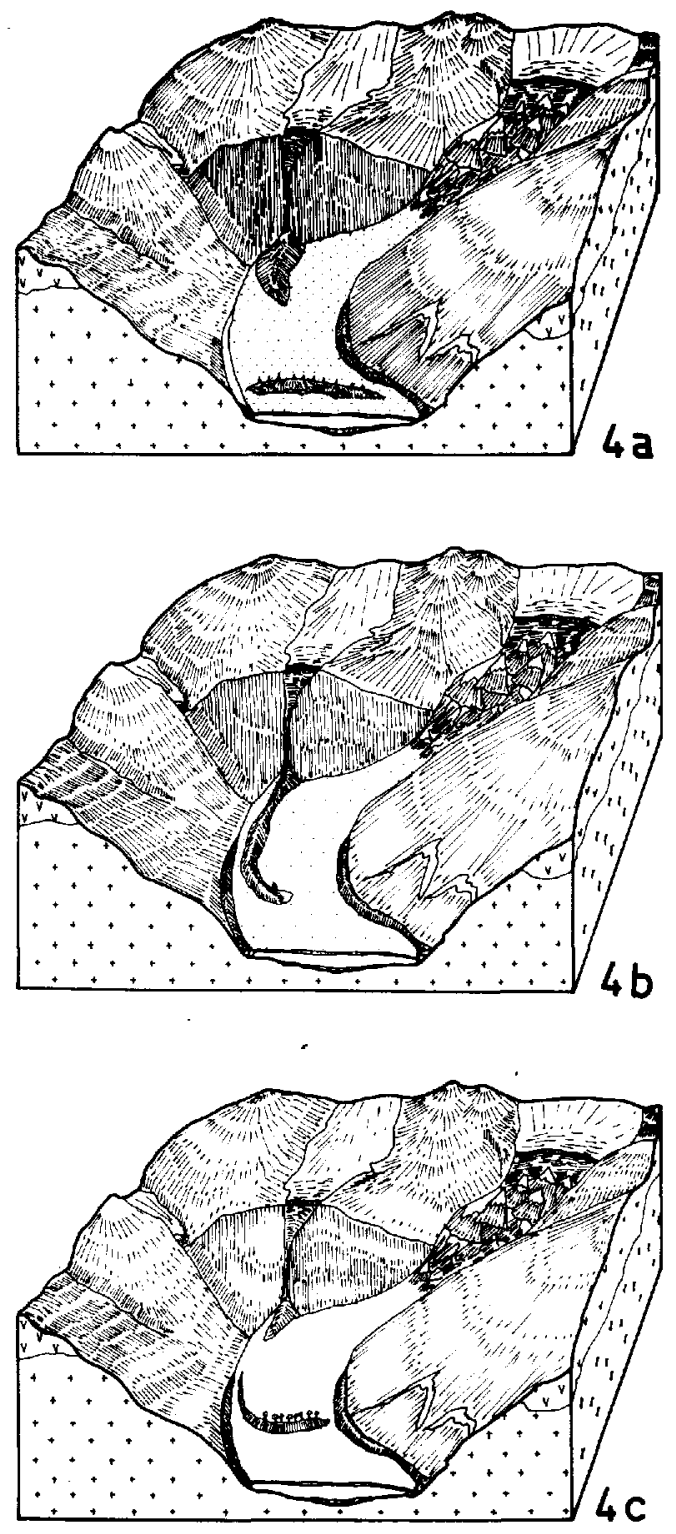

Fig. 4. Schematic block-diagrams (out of scale) showing the genesis and evolution of a moraine in-transit arc on the surface of Casa Pangue glacier. 
regenerated tongue, where depressions are not found at the glacier margins. Along the lower portions, debris contributed by landsliding and avalanches (Fig. 3) does not reach the surface, but is taken away by melt-water streams along the glacier side or beneath it. In the past, landslides from lateral walls may have extended over the surface of the glacier at lower altitudes.

The thickness of the supraglacial till is much deeper on the morainic arcs $(3$ to $4 \mathrm{~m}$ ) than on the rest of the glacier surface $(0.2$ to $1.0 \mathrm{~m})$ (Fig. 2). Once the arc is stabilized and equilibrium is attained on its slopes, it keeps moving passively with the ice, at a progressively slower rate as it approaches the glacier snout (Fig. 4c)

Supraglacial till is the parent material for soil development and the growth of vegetation. Soils are young; no true soil horizons were observed, except for an uppermost organicdebris layer in those areas where the forest is denser. This layer strongly resembles, in surficial characteristics, podzols of neighbouring areas. Soils were sampled at the densely vegetated morainic arc no. 4 and at the depressed areas between arcs nos. 3 and 4 , where vegetation is scarce and trees are small. Granulometric and petrographical composition appear similar in both areas. Soils are acid ( $\mathrm{pH} 4.6$ to 4.7 ) but acidity is not related to soluble salts, for the $\mathrm{pH}$ of extracted material rose abruptly to 6.45 to 6.60 . This was confirmed by high values of resistivity. Nitrogen (0.01 to $0.02 \%)$ and organic matter $(0.1$ to $0.2 \%$ ) are almost absent, showing the incipient pedogenic evolution. Calcium content is low, and potassium content is high for Andean soils, as far as is known. This may be related to the weathering of volcanic ashes. Phosphorus content is considered to be medium. However, calcium, potassium, and phosphorus contents are higher in the samples taken at the morainic arcs, thus probably indicating some pedogenic influence of the forest.

\section{DISCUSSION AND CONCLUSIONS}

The finding of tree communities on supraglacial till and on moving ice presents some exciting problems.

It is not a unique phenomenon: Río Blanco glacier also has large trees growing on supraglacial moraines. Colonization seems to be continuous through time, perhaps not much later after the genesis of the arcs. These arcs are formed by supraglacial till and should be considered as depositional supraglacial features They are not differentially-melted ogives or kinematic waves passing along the glacier tongue. The arcs are higher than the neighbouring depressions, but this may be considered an effect of insulation by the thicker till cover, which protects the underlying ice. This would explain the persistence of the ice-crests under the arcs, and agrees with the observations of Reid (1969[a] and [b], 1970[a] and [b]), Reid and Callender (1965), Post (1967), and Marangunic and Bul1 (1968), among others. Supraglacial till originated mainly as landslide debris and partially as rock avalanches on the glacier surface. Mass-movement processes and supraglacial streams contributed to a regular distribution of the rock fragments over the surtace. However, thicker debris masses provided by landsliding have conserved most of their original morphology. Although thrusting may be present at the snout, no thrust ridges were observed at the glacier surface.

Arcs have been moving actively, at least since 1942. This has been indisputably proved by interpretation of air photographs and of rotated marginal crevasses (i.e. shear crevasses pointing up-glacier). If glacier movement existed before 1942, and if movement rates were similar, trees of the outermost arcs, which germinated not later than 1930, have travelled more than 1000 to $1200 \mathrm{~m}$. When a morainic arc reached the snout of the glacier, it collapsed because of melting of the ice. This was shown by the disappearance of arc no. 1 , sometime between 1942 and 1953 . Its constituent materials, both supraglacial till and collapsed vegetation, have been incorporated into the terminal, ice-contact moraines. Tree trunks were fragmented in the highly energetic environment, and pieces of wood are found among the till.

Processes of supraglacial sedimentation on Casa Pangue glacier (and other debris-covered glaciers of the area) were increased, supposedly, sometime after the end of the Llanquihue glaciation, i.e. $14 \mathrm{ka} \mathrm{BP} \mathrm{(Mercer} \mathrm{1976),} \mathrm{when} \mathrm{the}$ thickness of the ice at the site of the present glacier tongue decreased progressively from $1200 \mathrm{~m}$ to $90 \mathrm{~m}$. Thus, the relative local relief of the valley increased strongly, and landsliding processes were favoured. It is more difficult to deduce when plant colonization of the arcs started. Soil development on the supraglacial cover seems to be rapid. According to the observed movement rates, till was deposited on the giacier surface < 150 to 200 a BP, at most. Plant colonization has been suggested for the last 45 to $50 \mathrm{a}$. This may be extended if we assume that the trees which inhabited the arc that collapsed between 1942 and 1953 were similar in age to those living today. Colonization would have started then, around the turn of the century. Moreover, the possibility of older tree-growth or even the recurrence of plant colonization during the Holocene should not be discounted. In fact, the Valdivian rain forest had optimum development between 8.5 and $6.5 \mathrm{ka}$ BP (Heusser 1974:312), and its distribution changed later on, as the climate fluctuated. since $2.5 \mathrm{ka}$ BP, according to Heusser (1974). pollen records suggest that climatic conditions were much the same as today. Thus, Nothofagus dombeyi may have grown on Casa Pangue glacier continuously or recurrently since $8.5 \mathrm{ka} \mathrm{BP}$ and, more probably, since $2.5 \mathrm{ka}$ BP. However, the glacier may have been too active during neoglacial times for trees to develop. N.dombeyi has been described as a species of great adaptability and as an active early settler in this region (Weinberger 1977, McQueen 1977). It modifies soil conditions and thus helps colonization by other trees and shrubs. However, the rapid movement of the glacier tongue prevents the full development of the entire plant community of the Valdivian rain forest, because morainic arcs collapse at the edge of the glacier tongue before colonization is completed. Trees and other plants growing on the glacier do not need a totally stable ground for their development. Casa Pangue glacier is a good example of an active substratum where plants develop successfully, including large crustose 7 ichens (some of them larger than $200 \mathrm{~mm}$ ) which live on the morainic arcs. Some questions arise then about the absolute validity of 1 ichenometric dating on deglaciated terrain, specially measurements of 1 ichens growing on boulders in areas with dead-ice topography.

Similar limitations should be expected for radiocarbon dating of wood fragments in environments such as those described here. Porter and Carson (1971) and Post and Streveler (1976) have 
Carson (1971) and Post and Streveler (1976) have coincident opinions on these topics. If radiocarbon dating is performed on wood fragments which may have grown in environmental conditions similar to those described in this paper, dates should be regarded carefully. The radiocarbon age of these fossil wood pieces would provide the age of the death of the tree, which may not be synchronous with a climatic event of glacial significance.

\section{ACKNOWLEDGEMENTS}

The authors are greatly indebted to the following: José A. Lúquez, Lic.Geol., for his participation in the 1978 field season; Adriana Ramassotto, Lic.Biol., University of Comahue at Bariloche, for dendrochronological analysis; Raúl Ortiz, Chem.Eng., INTA-Bariloche, for chemical analysis of soil samples; and Maria A. de Saura, Lic.Biol., University of Comahue at Bariloche, and C. Cazzola, Agr. Eng., INTA-Bariloche, for the aid in plant identification. The authors are also grateful to all those who kindly discussed with us several aspects of the paper at the University of La Plata, INTA-Bariloche, University of Comahue at Neuquen, and IANIGLA-Mendoza, and those who corresponded with J. Rabassa on these topics: Professors C.J. Heusser, A. Dreimanis. S.C. Porter, and J. Matthews, and Drs A. Post, L.Lliboutry, and A. Brandani.

\section{REFERENCES}

Clayton L 1964 Karst topography on stagnant glaciers. Joumal of Glaciology $5(37): 107-112$

Colqui B 1970 Glaciología de la cuenca del Río Manso Superior. Anales de la Sociedad Argentina de Estudios Geograficos GAEA (Buenos Aires) 14: 13-24

Flint R F, Fidalgo $F$ 1964 Glacial geology of the east flank of the Argentine Andes between latitude $390^{\circ} 10^{\prime} \mathrm{S}$ and latitude 41020 ' S. Geological Society of America Buzzetin 75(4): 335-352

Heusser C J 1972 Polsters of the moss Drepanocladus berggreni on Gilkey Glacier, Alaska. Bulletin of the Torrey Botanical club (New York) 99(1): 34-36

Heusser C J 1974 Vegetation and climate of the southern chile lake district during and since the last interglaciation. Quaternary Research 4(3): 290-315

Heusser C J, Flint R F 1977 Quaternary glaciations and environments of northern Isla Chiloé, Chile. Geology 5(5): 305-308

Kölliker A, Kühn F, Reichert F, Tomsen A, Witte L 1917 Patagonia; resultados de las expediciones realizadas en 1910 a 1916 . Tomo 1, 2. Buenos Aires, Compañi a SudAmericano de Billetes de Banco

Lliboutry L A 1956 Nieves y glaciares de Chite: fundamentos de glaciologí. Santiago de Chile, Universidad de Chile

McQueen DR 1977 The ecology of Nothofagus and associated vegetation in South America. Twatara 22(3): 233-244

Marangunic C, BuTl C B B 1968 The landslide on the Sherman Glacier. In the great Alaska earthouake of 1964. Hydrology. Washington DC, National Academy of Sciences: $383-394$ (Publication No 1603)

Matthews J A 1973 Lichen growth on an active medial moraine, Jotunheimen, Norway. Joumaz of Glaciology 12(65): 305-313

Mercer J H 1967 Southern hemisphere glacier atias. Natick, Mass., US Army Natick Laboratories (Technical Report 67-76-ES)
Mercer J H 1976 Glacial history of southernmost South America. Quaternary Research $6(2): 125-166$

Miller D J 1957 The surface velocity of the Yakataga Glacier, Alaska. Joumal of Glaciology $3(22): 125-130$

Odell NE 1948 Stagnant glacier in British Columbia. Joumaz of Glaciology 1(4): 191

Paskoff R 1977 Quaternary of Chile: the status of research. Quatemamy Research $8(1): 2-31$

Porter S C, Carson R J III 1971 Problems of interpreting radiocarbon dates from deadice terrain, with an example from the Puget Lowland of Washington. Quatemary Research 1(3): 410-414

Post A S 1967 Non-earthquake origin of supraglacial debris on Martin River and Sioux glaciers, Alaska. Joumal of Gzaciology 6(48): 953-956

Post A S, Streveler G 1976 The tilted forest: glaciological-geologic implications of vegetated neoglacial ice at Lituya Bay, Alaska. Quatemary Research 6(1): 111-117

Rabassa J, Rubulis S, Suarez J 1978 Los glaciares del Cerro Tronador, Parque Nacional Nahuel Huapi, Río Negro,

Argentina. Anales de Parques Nacionazes (Buenos Aires) 14: 275-318

Rabassa J, Rubulis S, Brandani A 1980 Eastwest and north-south snow line gradients in the northern Patagonian Andes, Argentina. Intemational Association of Soientific Hydrology Publication 126 (Workshop at Riederalp 1978 - World Gracier Inventom): 1-10

Reichert $i \quad 1927$ El macizo de Tronador. Anales de Za Sociedad Argentina de Estudios Geográficos GAEA (Buenos Aires) 2(3): 385406

Reid J R 7969[a] Effects of a debris slide on "Sioux Glacier", south-central Alaska. Journal of GLaciology 8(54): 353-367

Reid JR [1969[b]] Glaciers - "]iving and dead". Proceedings of the North Dakota Academy of Science 21(1) 1967: 42-56

Reid J R 1970[a] Geomorphology and glacial geology of the Martin River Glacier, Alaska. Arctic 23(4): 254-267

Reid JR 1970[b] Late Wisconsin and neoglacial history of the Martin River Glacier, Alaska. Geological Society of America Bulzetin 81(12): 3593-3603

Reid J R, Callender E 7965 Origin of debriscovered icebergs and mode of flow of ice into "Miller Lake", Martin River Glacier, Alaska. Joumal of Glaciology 5(40): 497503

Russel1 I C 1893 Malaspina Glacier. Joumal of Geology 1(3): 379-245

Seton Karr HW 1887 Shores and alps of AZaska. London, Sampson Low, Marston, Searle and Rivington

Sharp R P 1958 The latest major advance of Malaspina Glacier, Alaska. Geogrophical Review 48(1): 16-26

Tarr R S, Martin L 1914 AZaskan glacier studies of the National Geographic Society in the Yakutat Bay, Prince Wiltian Sound and Lower Copper River regions. Washington DC, National Geographic Society

Weinberger $P 1977$ The regeneration of the Araucano-Patagonic Nothofagus species in relation to microclimatic conditions Tuatara 22(3): 245-265 